IRSH 57 (2012), Special Issue, pp. 97-I 28 doi:I0.10I7/So0208590 $200044^{2}$ (C) 2012 Internationaal Instituut voor Sociale Geschiedenis

\title{
The League of Nations and the Moral Recruitment of Women*
}

\author{
MA G A LY R O D ÍG UEZ GARCÍA \\ Vrije Universiteit Brussel/Research Foundation Flanders (FWO) \\ E-mail: mrodrigu@vub.ac.be
}

\begin{abstract}
Summary: This article analyses the debate on trafficking and policies to combat the recruitment of persons for commercial sex within the Advisory Committee on the Traffic in Women and Children of the League of Nations. Its main argument is that the Committee's governmental and non-governmental representatives engaged in what might be called a "moral recruitment of women". This form of recruitment had a double purpose: to protect females from prostitution through the provision of "good employment", and to repress intermediaries of prostitution by means of criminalization. Three elements of the Committee's internal debates and concrete actions will receive special attention. Firstly, the ideological framework (feminism, social purity, humanitarianism, abolitionism, regulationism, and/or class); secondly, the gender dynamics (differences of opinion between the Committee's male and female representatives); and thirdly the degree of gendering (construction or reinforcement of gender roles and relations).
\end{abstract}

World interconnectedness increases not only the mobility of people, customs, resources, and ideas within and across national borders, but also the fear of spreading crime and diseases. Tougher controls and repression are the inevitable corollary of such a process. As noted by the former Secretary General of the United Nations, Kofi Annan, in the foreword to a report on the 2000 Convention against Transnational Organized Crime,

\footnotetext{
* I am indebted to Jean-Michel Chaumont for his generous sharing of information about the League of Nations Archives [hereafter LNA] at the United Nations Office, Geneva; and to Olivier de Maret, Daniëlle De Vooght, Anneke Geyzen, Paul Knepper, Lex Heerma van Voss, and the editors of this journal's special issue for their constructive remarks and reading suggestions. Needless to say, the opinions expressed in the present study are my own. I would also like to record my special thanks to Jacques Oberson and Lee Robertson for their professional and friendly assistance during my research in the Geneva archives; and to Paul Bullard for his careful proof-reading of this article. I am a Postdoctoral Fellow of the Research Foundation Flanders (FWO), Belgium, which facilitated my stay in Geneva by the award of a mobility grant.
} 
"if crime crosses borders, so must law enforcement"; ${ }^{\mathrm{I}}$ special attention is paid to the recruitment of persons for prostitution. ${ }^{2}$

Alarming reports on international crime, and human trafficking in particular, are not new, however. Since the nineteenth century, trafficking in women and girls for prostitution has attracted great attention. ${ }^{3}$ Information about the so-called white slave trade - initiated by British reports on the "abduction" of English women to continental brothels and the "sexual slavery" of European females in South America - spread rapidly during the i 870 s and led to the formation of the first anti-trafficking movement. ${ }^{4}$ At the end of the nineteenth and beginning of the twentieth centuries, efforts to prevent and combat trafficking in persons resulted in the organization of a series of conferences and the passage of national laws and international conventions.

During the interwar period, the League of Nations strengthened the legal instruments aimed at the suppression and prevention of international crime. ${ }^{5}$ In I 92 I - in cooperation with anti-traffic voluntary organizations it first addressed the recruitment of persons for purposes of prostitution by approving the International Convention for the Suppression of the Traffic in Women and Children. In subsequent years, the League and its anti-traffic committee contributed to perfecting a "global prohibition regime" ${ }^{\prime 6}$ against international sex trafficking and the direct or indirect recruitment for prostitution that endures to this day. ${ }^{7}$

I. United Nations Convention against Transnational Organized Crime and the Protocols Thereto, United Nations, 2004, p. iii, available at: http://www.unodc.org/documents/treaties/ UNTOC/Publications/TOC\% 20 Convention/TOCebook-e.pdf; last accessed 29 November 20II. For a comprehensive overview of cross-border crime and crime control, see Peter Andreas and Ethan Nadelmann, Policing the Globe: Criminalization and Crime Control in International Relations (New York, 2006).

2. "Annex II: Protocol to Prevent, Suppress and Punish Trafficking in Persons, Especially Women and Children, Supplementing the United Nations Convention against Transnational Organized Crime”, in United Nations Convention against Transnational Organized Crime and the Protocols Thereto, p. 42.

3. Paul Knepper, The Invention of International Crime: A Global Issue in the Making, I88I-I9I4 (London, 2010), p. 98.

4. Donna J. Guy, White Slavery and Mothers Alive and Dead: The Troubled Meeting of Sex, Gender, Public Health and Progress in Latin America (Lincoln, NE [etc.], 2000); Stephanie A. Limoncelli, The Politics of Trafficking: The First International Movement to Combat the Sexual Exploitation of Women (Stanford, CA, 2010).

5. Paul Knepper, International Crime in the 2oth Century: The League of Nations Era, 1919-1939 (London, 20II).

6. Ethan A. Nadelmann, "Global Prohibition Regimes: The Evolution of Norms in International Society", International Organization, 44 (1990), pp. 479-526. For the application of the concept of global prohibition regimes in the fight against sexual trafficking in contemporary Greece, see Georgios Papanicolaou, "The Sex Industry, Human Trafficking and the Global Prohibition Regime: A Cautionary Tale from Greece", Trends in Organized Crime, I I (2008), pp. 379-409.

7. The UN Protocol to Prevent, Suppress and Punish Trafficking in Persons, Especially Women and Children (in force since December 2003) contains much of the League's gendered logic with 
This article analyses the debate on trafficking and policies to combat the recruitment of persons for commercial sex within the Advisory Committee on the Traffic in Women and Children of the League of Nations (henceforth "Committee"). ${ }^{8}$ The Committee seldom used the word "recruitment". Most often, its members used verbs such as to "incite", "entice", and "lead away", or the term "intermediary of prostitution", probably to emphasize the illegal and presumed exploitative character of the recruiters" activities. "Recruitment" and "intermediary of prostitution" are used in this article to encompass all persons who directly or indirectly facilitate women entering the world of prostitution. As the narrative unfolds, the difference between traffickers, procurers, brothel keepers, and souteneurs (pimps), as well as the Committee's proposals to punish them, will be specified. With the exception of its US experts, the Committee almost invariably used the word "souteneur" instead of "pimp". This was most likely a result of the common usage of French during the Committee's meetings. In this article, I will employ both terms for the activity of pimping. As with the word "prostitute", I am aware of the pejorative connotation and vague definition of the terms "pimp" or "souteneur". Those involved in the prostitution milieu often use the less deprecating - but also less clear - words "boy" and "girl" instead of "pimp" and "prostitute"; furthermore, they make no distinction between procurers and pimps. Since this article primarily focuses on the debates within the League of Nations, I prefer to adhere to the terms used within the Committee.

The main argument of this article is that the Committee's governmental and non-governmental representatives engaged in what might be called a "moral recruitment of women". This notion is inspired by Howard Becker's concept of “moral entrepreneurs" and Ethan Nadelmann's "transnational

regard to traffic and prostitution in general. Unlike the 1949 UN Convention for the Suppression of the Traffic in Persons and of the Exploitation of the Prostitution of Others, the new convention includes the issue of coercion and deception in its definition of trafficking. However, the definition is so broad that it could include cases in which the question of force or consent is unclear; United Nations Convention against Transnational Organized Crime and the Protocols Thereto - Conference of the Parties to the United Nations Convention against Transnational Organized Crime, available at http://www.unodc.org/unodc/en/treaties/CTOC/ index.html\#Fulltext; last accessed 29 November $20 \mathrm{I}$ I. For a critical view on the negotiations for the UN Trafficking Protocol, see Jo Doezema, "Who Gets to Choose? Coercion, Consent, and the UN Trafficking Protocol", Gender and Development, I0 (2002), pp. 20-27.

8. This League of Nations unit adopted various names during the I920s and I930s: Advisory Committee on the Traffic in Women and Children (I92 I-I924), Advisory Committee on Traffic in Women and Protection of Children (1924-1925), Advisory Commission for the Protection and Welfare of Children and Young People - Traffic in Women and Children Committee (1925-1936), and Advisory Committee on Social Questions (1936-1939). These changes reflect the Committee's shifting focus, from a specific issue within commercialized sex - trafficking to prostitution in general; Victor Yves Ghébali and Catherine Ghébali, A Repertoire of League of Nations Serial Documents, 1919-1947 (New York, 1973), p. 6 10. 
moral entrepreneurs", meaning "those who 'operate with an absolute ethic' in seeking to create new rules to do away with a perceived great evil".? Proselytism plays a key role within the process of rule creation and enforcement, as reformers follow their morals when attempting to make rules or to alter the existing ones that do not satisfy them. But, as Becker comments, a reformer is not merely a "meddling busybody, interested in forcing his own morals on others". Reformers are often concerned with humanitarian issues and believe that the reform they propose "will prevent certain kinds of exploitation of one person by another". He also noticed that reformers are commonly "more concerned with ends than with means" and rely on the advice of experts for drawing up rules. ${ }^{\text {IO }}$

As the Committee's discourse revealed these two dimensions - morality and humanitarianism - and as its concrete initiatives on behalf of prostitutes placed great emphasis on the provision of "good employment" II for women, I believe the notion of a "moral recruitment" fittingly depicts its commitment to fight sex traffic and - albeit not officially - prostitution in general. This form of recruitment was meant to rescue females from "social evils connected with prostitution", ${ }^{\mathrm{I} 2}$ and to repress intermediaries of prostitution by means of law enforcement principles. ${ }^{13}$ The Committee perceived these moral/humanitarian and repressive approaches as complementary, although there was a clear hierarchy. Law enforcement would be guaranteed by international and national authorities (through international conventions aimed at the convergence of national legislations), while protection and rescue work would be the main concern of non-governmental organizations. Whether the proposed measures effectively protected persons from being trafficked and punished genuine criminals, or rather triggered legal and social means that ended up limiting the freedom of alleged victims and offenders, is open to debate. Further research and a different sort of primary source are required to shed more light on this issue.

9. Howard Becker, Outsiders: Studies in the Sociology of Deviance (New York, 1963), p. I48; Nadelmann, "Global Prohibition Regimes", pp. 48 I-482, n. 4.

ı. Becker, Outsiders, pp. I48, iso.

I I. League of Nations Advisory Committee on the Traffic in Women and Children, Minutes of the First Session [hereafter, "Committee, Minutes of ..."], Geneva, 28 June-I July 1922, p. 8, LNA C.445.M.265.1922.IV.

I2. League of Nations, Report of the Special Body of Experts on Traffic in Women and Children, 2 parts (Geneva, 1927), Part I, p. 6, LNA, C.52.M.52.1927.IV.

I3. Investigation and prosecution of traffickers on the one hand, and protection of and assistance to the victims of trafficking on the other, are also included in the UN Trafficking Protocol of 2003 . For a critical analysis of the current debate on and campaign against trafficking, see Brenda Carina Oude Breuil et al., "Human Trafficking Revisited: Legal, Enforcement and Ethnographic Narratives on Sex Trafficking to Western Europe", Trends in Organized Crime, I4 (20II), pp. 30-46. 
The article's structure follows Ethan Nadelmann's “evolutionary pattern” towards global prohibition regimes. The first section examines the situation prior to 1927, when the Committee largely ignored the issue of recruitment. The second section focuses on the affirmation of the existence of trafficking in women and the redefinition of recruitment for prostitution "as a problem and as an evil". ${ }^{\mathrm{I}}$ "The third and fourth sections analyse the Committee's activism and the problems involved in it for the identification and criminalization of recruitment on the one hand, and for the protection of victims and potential victims on the other. In every section, three elements of the Committee's internal debates and concrete actions will receive attention: firstly, the approaches (feminism, social purity, humanitarianism, abolitionism, regulationism, and/or class) that provided the framework in which the Committee operated; secondly, the gender dynamics (differences of opinion between male and female representatives within the Committee); and thirdly, the degree of gendering (construction or reinforcement of gender roles and relations) and the basis of the Committee's dichotomous view of (female) "victims" and (male) "perpetrators" in the sex industry.

\section{THE ORIGINS OF ANTI-TRAFFICKING AND THE COMMITTEE'S INITIAL ACTIVISM}

The campaign against human trafficking can be traced back to the second half of the nineteenth century. However, the first anti-trafficking movement was not monolithic. ${ }^{\text {Is }}$ Abolitionism - the movement to eliminate state-regulated prostitution - appeared for the first time in Great Britain and gained strong support among feminist organizations from various parts of the world. Opponents of regulation viewed this form of state control of women not only as morally unacceptable and inefficient (clandestine prostitutes and male clients were not part of the system), but also as dangerous because it allegedly promoted "national and even international traffic and commerce in prostitutes". ${ }^{16}$ A shift from the original purpose of abolitionism became clear as abolitionists began to draw a stronger link between licensed prostitution and trafficking. ${ }^{17}$

14. Nadelmann, "Global Prohibition Regimes”, pp. 484-485.

I5. Limoncelli, Politics of Trafficking, p. 7.

16. Sheldon Amos, A Comparative Survey of the Laws in Force for the Probibition, Regulation and Licensing of Vice in England and Other Countries (London, 1877), quoted in League of Nations, Report of the Special Body of Experts: Part I, p. 7. For an overview of the involvement of the first leader of the abolitionist movement, the British feminist Josephine Butler, in the campaign against the "white slave trade", see Susan Mumm, "Josephine Butler and the International Traffic in Women”, in Jenny Daggers and Diana Neal (eds), Sex, Gender, and Religion: Josephine Butler Revisited (New York, 2006), pp. 55-7I.

17. Petra de Vries, "Josephine Butler and the Making of Feminism: International Abolitionism in the Netherlands (I870-I9I4)", Women's History Review, I7 (2008), pp. 257-277, 259-260. 
By the late I 890 , a movement for the suppression of "white slave traffic" emerged in Britain and was institutionalized under the name International Bureau for the Suppression of Traffic in Women and Children [hereafter, "International Anti-Traffic Bureau"].

One important difference between the two organizations was that the International Anti-Traffic Bureau did not denounce state-regulated prostitution - perceived as a necessary control mechanism - and focused solely on international trafficking. Furthermore, the first-generation abolitionists were strongly influenced by liberal ideas that opposed patriarchal oppression and state intervention in private matters, while social purity dominated the International Anti-Traffic Bureau's campaign against trafficking. ${ }^{18}$ However, from the early twentieth century onward, the socialpurity discourse gained ground among abolitionists and feminists. ${ }^{19}$ For its part, feminism itself was by no means homogeneous; many different views on questions of morality existed among internationally organized women. ${ }^{20}$

After some successes at national level, the anti-trafficking movement proceeded to the international arena to press for the suppression of traffic in women. In the early twentieth century, the first international agreements against "white slave traffic" were approved. ${ }^{21}$ At the end of World

I 8. Anne Summers, "Which Women? What Europe? Josephine Butler and the International Abolitionist Federation”, History Workshop Journal, 62 (2006), pp. 214-23 I, 2 I7; Limoncelli, Politics of Trafficking, pp. 44-48, 57-58.

19. Deborah Stienstra, "Madonna/Whore, Pimp/Protector: International Law and Organization Related to Prostitution", Studies in Political Economy, 51 (1996), pp. I83-217, I87-188; De Vries, "Josephine Butler and the Making of Feminism", p. 260. Limoncelli, Politics of Trafficking, tends to portray the first anti-trafficking movement in binary terms: the International Abolitionist Federation is perceived as feminist, progressive, humanitarian, and transnational, while the International Anti-Traffic Bureau, along with the religious voluntary assessors and delegates from regulationist countries represented in the League's Committee, are often depicted as conservative, repressive, and nationalist. A thorough analysis of the Committee's anti-trafficking activity reveals a more complex picture.

20. For instance, most of them supported a single moral standard for both sexes, but many women interpreted it in different ways. One feminist brand supported female sexual integrity as the desired norm for both men and women, while another group understood the common standard as implying greater (sexual) permissiveness for women, akin to that for men; Leila J. Rupp, Worlds of Women: The Making of an International Women's Movement (Princeton, NJ, 1997), pp. I 50, I 54. Evidence from the minutes and reports of the League's Committee indicate that most female representatives tended to read the single moral standard for men and women in terms of continence. According to the representative of the International Women's Organizations and well-known French feminist/abolitionist Avril de Sainte-Croix, it was "the duty of parents to bring their sons up in the same atmosphere of purity as their daughters"; Committee, Minutes of the Fifth Session, Geneva, 22-25 March 1926, p. 92, LNA C.233.M.84.1926.IV.

2I. In 1904, the International Agreement for the Suppression of the White Slave Traffic was adopted. It included the appointment of central authorities to gather information on trafficking, the supervision of employment agencies that sent women abroad, and the vigilance of ports and railway stations for putative procurers and victims. In I910, the International Convention for the Suppression of the White Slave Traffic was signed, covering the offence of procuring adult 
War I, Article 23c of the League of Nations Covenant entrusted the League with monitoring the agreements on the traffic in women and children. A survey revealed that many countries had not complied with the I9I0 Convention, so the League proceeded to organize an international conference in June I92 I. ${ }^{22}$ Four important decisions were taken during this conference. First, the racialized term "white slave traffic" was replaced by "traffic in women and children". ${ }^{23}$ Second, governments and voluntary associations were requested to send annual reports on trafficking and on the legal and social measures taken to suppress it. Third, a new convention was proposed. Fourth, the conference suggested the establishment of a special committee to investigate and to advise the League's Council and Assembly on conditions and measures against the international traffic in women and children. ${ }^{24}$

In September I92I, the International Convention for the Suppression of the Traffic in Women and Children supplemented the provisions of earlier international agreements by extending the protection to women of twenty-one and to minors of either sex. ${ }^{25}$ An Advisory Committee on the Traffic in Women and Children was set up, consisting of government delegates and five non-governmental assessors representing the main international organizations that dealt with the suppression of traffic. ${ }^{26}$ The Committee often made use of lawyers, experts on criminal and

women by means of fraud, violence, or other forms of compulsion, and of women under the age of twenty even with their consent; League of Nations Advisory Committee on Social Questions [hereafter, "Committee on Social Questions"], Report of the Sub-Committee entrusted with the drawing up of the Second Draft of a Convention for Suppressing the Exploitation of the Prostitution of Others, Geneva, I6 August 1937, pp. 2-3, LNA, C.33 r.M.223.1937.IV.

22. Karen Offen, European Feminisms, $1700-1950$ (Stanford, CA, 2000), p. 355.

23. As Leila Rupp, Worlds of Women, pp. 2 I I-2 I2, 216, comments, several women's organizations objected "to the lumping together of women and children", but they celebrated the League's initiative to continue the fight against traffic. The treatment of women and children as one group with comparable problems or facing similar dangers symbolizes the paternalism of the League's system. Many within the League of Nations seemed to have believed that women and children needed protection because they were "the least able to look after themselves"; Committee, Minutes of the Third Session, Geneva, 7-I I April 1924, p. 25 , LNA C.217.M.71.1924.IV.

24. League of Nations, Report of the Special Body of Experts: Part I, pp. 5, 8.

25. League of Nations Report to the Council by the Advisory Committee on Traffic in Women and Children, First Session, Geneva, 28 June-I July 1922, pp. 2-I 2, LNA A.9(I).r922.IV.

26. The governments of Denmark, France, Great Britain, Italy, Japan, Poland, Romania, Spain, and Uruguay were invited to appoint a representative, as well as the following private organizations: the International Bureau for the Suppression of Traffic in Women and Children, the International Catholic Association for the Protection of Girls, the Federation of National Unions for the Protection of Girls, the International Women's Organizations, and the Jewish Association for the Protection of Girls and Women; League of Nations Report to the Third Assembly of the League on the Work of the Council and on the Measures taken to execute the Decisions of the Assembly, Geneva, 1922, pp. 72-73, LNA A.6.1922. 


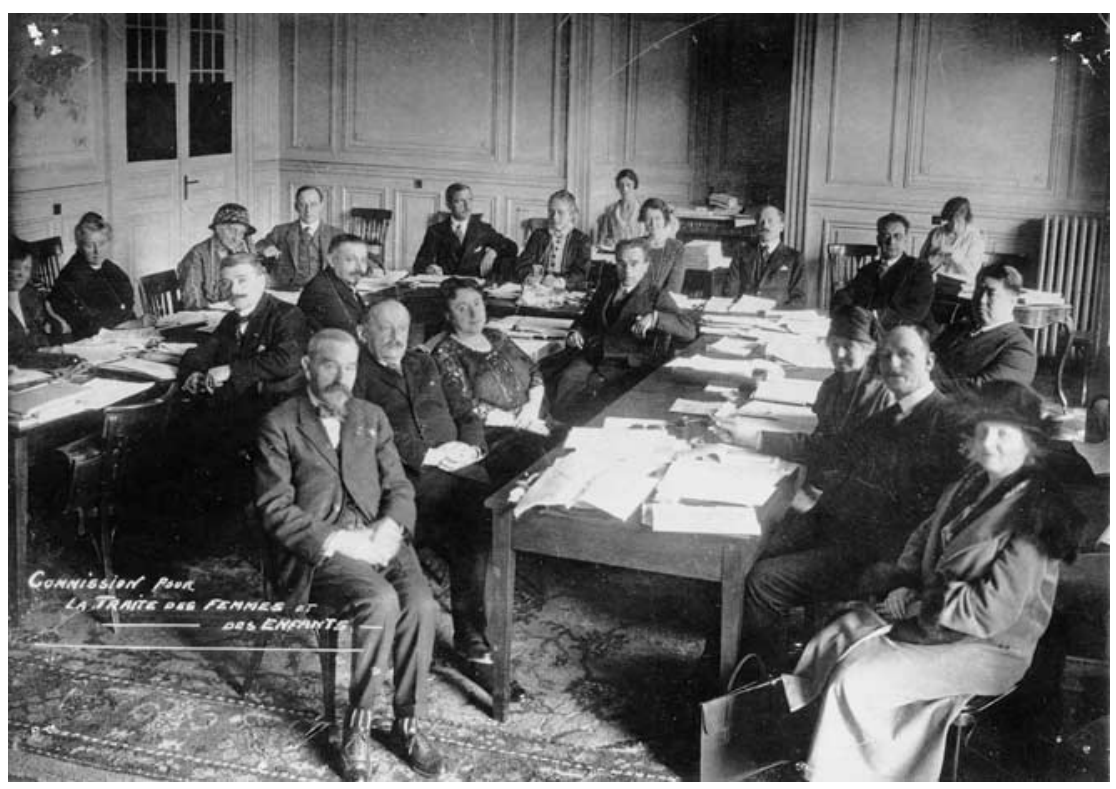

Figure I. League of Nations Advisory Committee on the Traffic in Women and Children. UNOG Library, League of Nations Archives, Geneva. Used with permission.

labour legislation, and (increasingly by the mid-I930s) psychiatrists. Like government delegates, non-official assessors were entitled to sponsor resolutions, propose reforms, add subjects to the annual agenda, and initiate debates, but they had no voting rights. ${ }^{27}$

During its first years of activity, the Committee focused on the tasks appointed by the League's Council: compilation of information on traffic; supervision of the efforts made by the signatories to conform to the international agreements on traffic; control of the situation with regard to the signatures of the I92 I Convention; and the monitoring of agencies engaged in finding employment for women abroad. It also urged competent national authorities and voluntary associations to keep an eye on the movements of women and girls who secured situations abroad independently of such agencies. In particular, engagements in theatres, music halls, and other places of entertainment were perceived as potential threats that could lead women

27. Barbara Metzger, "Towards an International Human Rights Regime during the Inter-War Years: The League of Nations' Combat of Traffic in Women and Children”, in Kevin Grant, Philippa Levine, and Frank Trentmann (eds), Beyond Sovereignty: Britain, Empire and Transnationalism, c.I880-1950 (New York, 2007), pp. 54-79, 59-6I; League of Nations, Report of the Special Body of Experts: Part I, p. 8; Report of the Sub-Committee [...] Second Draft of a Convention for Suppressing the Exploitation of the Prostitution of Others, August 1937, p. 3. 
to prostitution. Besides these core issues, the Committee paid great attention to female migration and the employment of foreign women in licensed brothels, which were considered to have a strong link with trafficking. The members of the Committee were sharply divided on these issues, but the gender dynamics of the debates did not always follow the lines one might expect. Not all female representatives to the Committee advocated the protection of women's rights and not all male delegates supported preventive measures that could have ended up depriving women of their freedom. ${ }^{28}$

The Committee was at odds over a proposal to prohibit the employment of foreign prostitutes in licensed brothels. Feminist abolitionists such as Paulina Luisi (Uruguayan delegate) and Avril de Sainte-Croix (representing the International Women's Organizations $)^{29}$ refused to support the proposal because it implied condoning licensed houses of prostitution, which they viewed as a "social evil" degrading to all women irrespective of their nationality. ${ }^{30}$ Gaston Bourgois $^{31}$ (French representative) also opposed the proposal because he saw in it an infringement of national sovereignty. Yet a large group within the Committee accepted the proposal as an "immediate compromise", which could lead to the abolition of the regulation of prostitution. Because of the established link between traffic and regulated prostitution, the Committee insisted on the necessity of obtaining detailed information about national legal systems with regard to commercial sex and about the prostitution milieu in general. ${ }^{32}$

28. See for example the contrasting views on female migration of Annie Baker (International Anti-Traffic Bureau's representative), who insisted on the need for strict migration legislation for young women, and of Samuel Cohen (Jewish Association for the Protection of Girls and Women) and Paulina Luisi (Uruguayan delegate), who called for the promotion of gender-neutral policies that would not interfere with the personal freedom of adult women; Committee, Minutes of the First Session, 1922, pp. I2, 24; Committee, Minutes of the Third Session, 1924, pp. 27, 39 .

29. For Luisi's role within the Uruguayan feminist movement, see Christine Ehrick, "Madrinas and Missionaries: Uruguay and the Pan-American Women's Movement”, in Mrinalini Sinha, Donna Guy, and Angela Woollacott (eds), Feminisms and Internationalism (Oxford, I999), pp. 62-80. For an overview of Avril de Sainte-Croix's activism, see Karen Offen, "Madame Ghénia Avril de Sainte-Croix, the Josephine Butler of France”, Women's History Review, 17 (2008), pp. 239-255. My findings on Avril de Sainte-Croix's opinions within the Committee sharply contrast with those of Karen Offen, who describes her views as "staunchly liberal, even radical, and secular in the tradition of the Declaration of Rights of Man as viewed through a feminist lens" (p. 242).

30. The following quotations are taken from: Reports on the Work of the Advisory Committee during its Second Session held at Geneva 22-27 March 1923, Geneva, August 1923, p. I0, LNA A.36.1923.IV; Committee, Minutes of the Second Session, Geneva, 22-27 March 1923, pp. I9, 24-25, LNA C.225.M.I29.1923.IV.

3I. Not to be confused with Léon Bourgeois (d. 1925), first President of the Council of the League of Nations and Nobel Peace Prize winner (1920).

32. Jessica Pliley, "Claims to Protection: The Rise and Fall of Feminist Abolitionism in the League of Nations' Committee on the Traffic in Women and Children, 1919-1936", Journal of Women's History, 22 (2010), pp. 90-1 I3, 91-105. 


\section{THE 1927 REPORT OF THE BODY OF EXPERTS}

In 1923, Grace Abbott (US delegate) ${ }^{33}$ proposed a thorough investigation of the nature of international traffic. In her view, the League of Nations needed to respond to the desire of world public opinion "to know the truth" about the traffic and the legal tools to combat it. ${ }^{34}$ The initiative followed the logic of what Michel Foucault called "the great procedure of investigation", in which "three conditions [make] it possible to ground judgement in truth: knowledge of the offence, knowledge of the offender and knowledge of the law".35 The proposed investigation aimed at establishing: the crime of trafficking, its authors, and measures for the legal punishment of recruiters and the protection of women and children. The League approved the US proposal and appointed a Special Body of Experts. It consisted of members of the League's Committee and the Director of the American Social Hygiene Association, the organization that provided the financial and human resources for the field enquiries. Undercover agents travelled to I 2 cities and districts to compile official and unofficial information from the prostitution milieu; they interviewed some 6,500 persons, including 5,000 people directly connected with the "underworld". ${ }^{36}$ The results of the investigation were summarized by the Body of Experts in a two-volume final report. It was the latter, rather than the unpublished field reports proper, ${ }^{37}$ that proved vital for the Committee's affirmation of the existence of trafficking and for its awakening to the question of recruitment. ${ }^{38}$

Until 1927, references to the issue of recruitment for prostitution were sporadic and almost exclusively made by the Committee's non-government

33. Germany and the United States were not (yet, in the German case) members of the League of Nations, but the Committee recommended that the Council invite those two countries to appoint representatives.

34. Committee, Minutes of the Second Session, 1923, pp. 6, 27, 61.

35. Michel Foucault, Discipline and Punish: The Birth of the Prison (Oxford, 1977), p. I9.

36. League of Nations, Report of the Special Body of Experts: Part I, pp. 5-6; Paul Knepper, "Spotlight and Shadow: The League of Nations and Human Trafficking in the I920s", paper presented to the European Social Science History Conference, Glasgow, I I-I 4 April 20 I 2.

37. The field reports of the First Enquiry on Traffic in Women and Children are classified per country and city in the LNA, boxes Si7I to $S_{1} 8$ I.

38. Katarina Leppänen, "Movement of Women: Trafficking in the Interwar Era", Women's Studies International Forum, 30 (2007), pp. 523-533, 528, argues that the "League of Nations took a non-moralising stand on the issue of prostitution and trafficking. Throughout the reports and investigations, it was the procurers and traffickers, if anyone, who were considered criminal or immoral - not the women". While it is true that the Body of Experts did not condemn prostitutes, it described trafficking as the "vilest of trades" and prostitution as a "public evil to be kept within the narrowest possible limits". Following this logic, prostitutes were victimized, while intermediaries of prostitution were described as "pests of society" and "real parasites"; League of Nations, Report of the Special Body of Experts: Part I, pp. 9, 48. For a dissection of the work of the Body of Experts, see Jean-Michel Chaumont, Le mythe de la traite des blanches. Enquête sur la fabrication d'un fléau (Paris, 2009). 
members. In its early activism, the Committee built from a foundation of its binary belief in weak and passive victims (or deviants in a few cases) on the one hand, and brutal and immoral perpetrators on the other. In the Committee's view, trafficking and prostitution in general constituted a world of unequal power relations. Although the I92 I Convention attempted to discover and prosecute whoever - men or women - engaged in the traffic of women and children of either sex, ${ }^{39}$ the Committee focused on female victims and male offenders. Furthermore, procurers, souteneurs, and traffickers were often identified as "alien", 40 "men of foreign race", ${ }^{41}$ or linked to Jewish identity. ${ }^{42}$

Gendered stereotypes were magnified by the Report of the Body of Experts. These experts established a close relationship between international traffic and "the national aspect of commercialised prostitution", and defined it in the widest possible sense:

[...] international traffic has been taken as meaning primarily the direct or indirect procuration of one or more other persons. This definition covers the cases in which girls have been procured and transported to become mistresses of wealthy men. It also covers certain cases of the procuring of women as entertainers and artists, and exploiting them for the purposes of prostitution in foreign countries under degrading and demoralising conditions.

So as to gain credibility, the Body of Experts attempted to avoid the sensationalism that characterized the earlier anti-trafficking campaign. Nonetheless, the shock value of the report was high. The Body of Experts admitted that trafficking did not involve the literal kidnapping of girls and stressed that it "did not wish to give the impression that all or most of these were unsuspecting and defenceless women who had been decoyed to a foreign country in ignorance of the real purpose of their journey".

39. International Convention for the Suppression of the Traffic in Women and Children, Geneva, 30 September I92 I, available at http://treaties.un.org/doc/Treaties/192I/09/19210930\% 2005-59\% 20AM/Ch_VII_3p.pdf; last accessed 29 November 201 I.

40. Committee, Minutes of the First Session, I 922 , pp. 37-38.

4I. The following quotations are taken from League of Nations, Report of the Special Body of Experts: Part I, pp. 9, I8-19, 22, 43-44.

42. Knepper, International Crime in the 20th Century, pp. I07-I I2. See also idem, "Jewish Trafficking' and London Jews in the Age of Migration", Journal of Modern Jewish Studies, 6 (2007), pp. 239-256. It is interesting to note the similarities in the picturing of the "victims" and "perpetrators" in the sex trade during the interwar period and in the past few decades. In the Netherlands, for example, the term "loverboy" was recently introduced to describe the actions of young, dark males (often of Moroccan or Antillean origin) who "entice" young, white, Dutch women to enter into prostitution. Current anxieties about human trafficking, however, focus primarily on women from low-income countries and the former Soviet bloc; Frank Bovenkerk et al., Loverboys of modern pooierschap (Amsterdam, 2006); Jo Doezema, "Loose Women or Lost Women? The Re-emergence of the Myth of 'White Slavery' in Contemporary Discourses of 'Trafficking in Women”, Gender Issues, I 8 (2000), pp. 23-50. 
However, the experts emphasized "that the practices of those now engaged in the traffic in women [...] still involve heartless fraud and cruelty". The report's authors estimated that about io per cent of the traffic was in minor girls and admitted that "a large number of foreign women met with were prostitutes before they went abroad". But, they added, "there is ample evidence for believing that a considerable proportion of them were originally induced to become prostitutes by some form of deceit or false pretence". A rationale suggesting that deceit and agency are necessarily exclusionary led the experts - along with many contemporary scholars and radical feminists ${ }^{43}$ - to conclude that most women found in foreign brothels were not free agents and thus that "a traffic of considerable dimensions" did exist.

Close reading of the final report, and more importantly of the original field reports, leads me to believe that the Body of Experts did not recognize that not all illegal migrants were victims of human trafficking. The undercover investigators did confirm the existence of a large migratory movement of men and women, as well as of informal networks that facilitated the recruitment and entrance of women into prostitution. They provided full details of the vast array of methods men and women had at hand to arrange the movement of females to overseas brothels: smuggling, marriage, employment contracts, facilitation of boat or train tickets, and provision of forged documents (visas, birth certificates, passports, invitation letters from family members living abroad, and so on). ${ }^{44}$ Furthermore, the undercover agents often reported on the existence of "sexual excesses" or "perversion" and debt bondage in the sex industry; references to "conditions of slavery" or "slave-girls" for prostitution, however, appear mainly in the experts' final report. ${ }^{45}$

43. The list of authors who concur with the definition and general findings of the Body of Experts with regard to sex trafficking is long. Most of these authors draw parallels between today's "sexual exploitation" and that of the second half of the nineteenth century and interwar period. A few examples are: Sheila Jeffreys, The Idea of Prostitution (North Melbourne, VIC, 1997); Leppänen, "Movement of Women"; Limoncelli, Politics of Trafficking; Metzger, "Towards an International Human Rights Regime"; Mumm, "Josephine Butler and the International Traffic in Women"; Pliley, "Claims to Protection".

44. League of Nations, Report of the Special Body of Experts: Part I, pp. 3 I-35.

45. Ibid., pp. I0, I4, 23; League of Nations, Report of the Special Body of Experts: Part 2, p. I77, LNA C.52(2).M.52.(I).1927.IV; Havana report, December 1924, LNA box SI73; Chaumont, Le mythe de la traite des blanches, pp. I $8 \mathrm{I}-20 \mathrm{I}$. Allusions to slavery were infrequent. Contrary to radical feminists, the Committee did not tend to refer to prostitution or trafficking as forms of slavery. The change in terminology in the anti-traffic conventions from "white slave traffic" to "traffic in women and children" reflected the reluctance of the League's experts to treat this form of labour as identical with slavery. Similarly, the League's Advisory Committee of Experts on Slavery focused on issues related to domestic slavery and slave-dealing proper (such as the legal ownership of persons, compulsory labour, and the transfer and inheritance of slaves) and made therefore no references to the forced recruitment of women for prostitution abroad. 
Yet, as with the debates on and campaigns against traffic in the late nineteenth and early twenty-first centuries, the interwar experts failed to distinguish between exploitative working conditions and actual trafficking. All cases of abuse in the sex trade were identified as traffic. This perspective denied women's agency, except when they decided to leave prostitution and consented to rehabilitation. ${ }^{46}$ Statements such as "even if a woman over age freely consents to being the object of the traffic, in the majority of cases she is not fully aware of the disaster to which she is being led" 47 symbolized the Committee's gendered and moralist view on so-called victims and perpetrators. Hence the Body of Experts and the Committee concluded not only that the crime of trafficking existed but also that its authors needed to be identified and prosecuted. Procurers and souteneurs were perceived as the main "agents of the traffic" because "prostitutes would not move from one country to the other on their own initiative" $4^{8}$ Therefore, it was of paramount importance to punish severely the intermediaries and to protect the victims and potential victims of trafficking.

\section{SUPPRESSION OF WOMEN'S RECRUITERS}

The Body of Experts treated the traffic in women and children as an illegal business activity governed by the laws of supply and demand. However, neither the experts nor the Committee as a whole focused on the demand for foreign prostitutes. Only towards the end of the r 930 s did the Committee very timidly tackle the issue of demand, concluding that "it is generally agreed that whatever the force of the natural sex impulse which lies at the root of prostitution, it is artificially stimulated by third parties who make their living by its exploitation". ${ }^{49}$ In its view, the

For a historical overview of the concept of "slavery" and the inclusion of prostitution, see Kevin Bales and Peter T. Robbins, "No One Shall Be Held in Slavery or Servitude': A Critical Analysis of International Slavery Agreements and Concepts of Slavery", Human Rights Revierw, 2 (200I), pp. 18-45.

46. The Italian representative, Princess Cristina Giustiniani Bandini, stressed the importance of consent for a successful rehabilitation of prostitutes; Committee, Minutes of the Fourteenth Session, Third Meeting, Geneva, 3 May i935, p. 3, LNA CTFE/r4th Session/PV.3.

47. Committee, Minutes of the Twelfth Session, Third Meeting, Geneva, 7 April 1933, p. 5, LNA CTFE/ 1 2th Session/PV.3.

48. Société des Nations. Sous-comité de la répression des agissements des souteneurs, Genève, 20 janvier I933, p. 2, LNA CTFE/CJ/2ème Session/PV.ı; translations from French are mine. 49. Committee on Social Questions, Prevention of Prostitution, Geneva, I7 February 1938, p. 4, LNA CQS/A/I6. In a 1947 brochure, a member of the abolitionist movement admitted that it was "high time that the International Abolitionist Federation should recognise the part men play in prostitution", and thanked the League's Committee for paying attention to this issue during one of its last sessions; A. Bouman, "The Part Men Play in Prostitution", International Abolitionist Federation Congress, Brussels, 8 September 1947, p. I. 
demand could be reduced by suppressing all forms of procuring, by providing counter-attractions to men (such as cultural centres, public libraries, cinemas, playing fields, and swimming pools), and by facilitating early marriage. ${ }^{50}$

The undercover investigators provided sufficient proof that transactions in the sex trade most often involved "intermediaries whose business is to recruit prostitutes". ${ }^{\text {I }}$ Prostitutes, pimps, traffickers, and madams all confirmed that many sex workers had "a boy" or "a sweetie" (often prostitutes' boyfriends or husbands, but invariably identified as regular "pimps" by the undercover agents) or had arranged their trip to another country through a third person, often a male. Many other prostitutes, however, also mentioned prostituted girlfriends, female relatives, or acquaintances who had persuaded them to enter into prostitution or helped them to go abroad. ${ }^{52}$ When or where women had not yet acquired sufficient political and socio-economic power to work as independent prostitutes, the tripartite organization of prostitution seemed practically inevitable. Furthermore, migratory impediments and labour restrictions, as well as stigma, marginalization, and violence, encouraged the involvement of third parties in the organization of prostitution. Bascom Johnson, Legal Director of the American Social Hygiene Association and Director of Investigations of the Body of Experts, claimed that only "prostitutes of the better class $[\ldots]$ go it alone and never have pimps". ${ }^{33}$

However, the relationship between prostitutes and souteneurs seems not to have been as asymmetric as generally assumed. Pimps moved from city to city to "secure recruits", while prostitutes actively looked for "boys" to help them out with travel tickets, money, forged documents, contacts with brothel keepers, and clients, and so on. ${ }^{54}$ The undercover agents also found various cases in which the traditional view of recruiting

50. Committee on Social Questions, Prevention of Prostitution, Geneva, Is May 1939, p. 23, LNA CQS/A/ı9(a); Committee on Social Questions, 1938, pp. 2, I I, LNA CQS/A/ı6, CQS/ $\mathrm{A} / \mathrm{I} 6(\mathrm{I})$.

5I. League of Nations, Report of the Special Body of Experts: Part I, p. 24.

52. See for example these field reports: Buenos Aires, June 1924 and Algiers, February I925, LNA box Si7i; Havana, December 1924, LNA box $\mathrm{S}_{173}$; Lyon, December 1924, Marseille, October 1924, and Paris, June-July 1926, LNA box Si74. See also Knepper, International Crime in the 2oth Century, p. 99. In their introduction to Maria Jaschok and Suzanne Miers (eds), Women E Chinese Patriarchy: Submission, Servitude and Escape (London [etc.], 1994), pp. I-24, I4-I 5 , the editors also stress that the role played by women in the exploitation of other women within the Chinese patriarchal system should not be overlooked.

53. Legal Sub-Committee, Activities of Souteneurs, Geneva, I I January 1933, p. 17, LNA $\mathrm{CTFE} / \mathrm{CJ} / 3$. Academic studies on pimps are even scarcer than those on prostitutes. As Ronald Weitzer, "New Directions in Research on Prostitution", Crime, Law and Social Change, 43 (2005), pp. 2II-235, 227, observes, "the little we know about pimps comes mainly from prostitutes, rather than from the pimps themselves".

54. Paris report, September 1924-September 1926, pp. 3, 5, LNA box Si74. 
for prostitution was turned upside down. For instance, French police and emigration officials stated that recruitment often went in two directions:

This recruitment of girls for prostitution, whether by souteneurs or others, is well known to the police of all countries and to the public generally. What is not so well known is the influence which professional prostitutes have in the recruitment of souteneurs [...]. Cases are known to exist of good-looking young men who, though of weak and idle natures, were not bad until infatuated by some experienced prostitute whose only means of keeping a companion and protector is to support him in the idleness to which he is naturally inclined.5s

Johnson added to the confusion about the "strange relationship" between prostitutes and souteneurs by stating that "in America, at least, as many pimps are created by prostitutes as there are prostitutes created by pimps, probably more, because, since the strengthening of our laws against third parties, they don't take any more chances than necessary". ${ }^{6}$ Johnson also argued that his international experience had taught him that the pimp-prostitute relationship was often as varied (respectful or abusive) as conventional relations between men and women or as common (either affectionate, violent, or degrading) as real marriages. Similarly, in his history of modern prostitution in France, Alain Corbin pointed to the "marital behaviour" of some pimp-prostitute relationships, as well as to the different ways persons involved in the prostitution milieu expressed their feelings. ${ }^{57}$

Indeed, members of the Committee seem to have had great difficulty in understanding the way that prostitutes and intermediaries of prostitution related to each other. Classist and stigmatizing statements often slipped into the discussion on the intimate bond and the refusal of many prostitutes to press charges against pimps. According to the Italian delegate to the Committee, Princess Cristina Giustiniani Bandini, “witnesses usually refused to speak, as they belonged to the same low ranks of society, and prostitutes retracted their own evidence under influence of fear, affection or some other feeling towards the souteneur". ${ }^{8}$ Therefore, none of the first-hand statements coming from prostitutes and pimps provoked a change in the Committee's gendered view of the division of labour, consisting of exploited women and exploitative men, in the sex industry. Between 1927 and 1939, when the League's activities stopped as a result of the outbreak of World War II, the Committee did its best to stamp out the direct or indirect recruitment of women for prostitution.

55. French report, December I924-January 1925, pp. IO-I I, LNA box Si74.

56. Legal Sub-Committee, Activities of Souteneurs, I933, pp. I6-18.

57. Alain Corbin, Women for Hire: Prostitution and Sexuality in France after 1850 (Cambridge, MA, I990), p. 156.

58. Committee, Minutes of the Twelfth Session, Fourth Meeting, Geneva, 7 April 1933, p. 7, LNA CTFE/r2th Session/PV.4(I). 


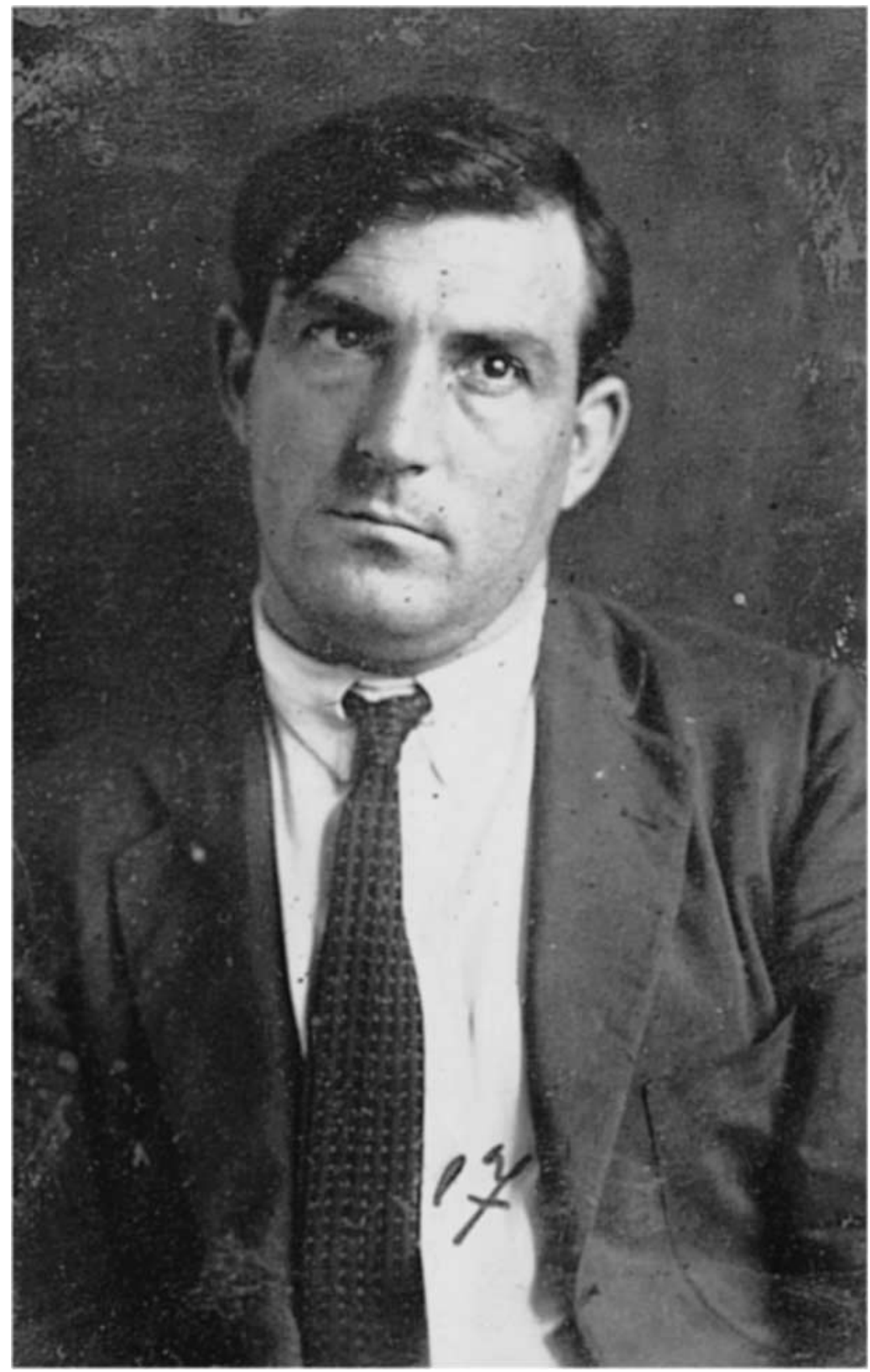

Figure 2. Photograph album of traffickers, souteneurs, and prostitutes, obtained from the chief of the judicial police, Havana (c.1927), "Souteneurs. Luis Lombardi - white race - son of Pedro and Rosa, born in Italy, 30 years old, single, con inst, unknown address, no more data." UNOG Library, League of Nations Archives, Geneva. Used with permission. 
The Committee's first target was the souteneur. After all, the Report of the Body of Experts made it clear that the prevailing international anti-traffic conventions already covered procuration (i.e. obtaining a person as a prostitute for another person) but did not yet cover pimping (i.e. controlling, protecting, and living on the earnings of a prostitute). Moreover, the experts stressed that by 1928 only a few countries (Canada and Great Britain for example) had "effective legislative measures" - such as flogging to punish the souteneurs. ${ }^{59}$ In other cases (Belgium being one), the offence of pimping fell under the heading of vagabondage, which allowed for the segregation of anyone with no visible means of existence. ${ }^{60}$

The need for order, normalization, and control moved the members of the Committee to focus on souteneurs. More so than procurers, pimps were considered particularly dangerous offenders because they were "obstinately averse to all honest work", "always outside the moral law and on the fringe of organised society". ${ }^{61}$ Supported by legal experts, the Committee also believed that most souteneurs sooner or later would become traffickers. Pre-emptive legal action was thus mandatory. Foucault would have interpreted the Committee's actions as an attempt to "provide the mechanisms of legal punishment with a justifiable hold not only on offences, but on individuals; not only on what they do, but also on what they are, will be, may be" ${ }^{62}$

All members of the Committee concurred in the need to punish souteneurs and to institutionalize the offence as an international crime. However, it seemed remarkably difficult to reach agreement on a precise definition of the offence. The difficulty arose because in many national legislations procurement and pimping were merged in the same clause. Thus, the difference between procurers and pimps was not always clear. Some Committee members used a comprehensive definition and perceived a souteneur as being guilty of three "violations": aiding and protecting

59. Great Britain reintroduced flogging for souteneurs in 1898 (under the Vagrancy Act) and for procurers in I9I2 (under the Criminal Law Amendment Act). The Belgian delegate to the Committee, Count Carton de Wiart, was particularly interested in this British law. He claimed not to be in favour of such measures, but he agreed that it might be necessary in dealing with extreme cases. Miss Wall, a British substitute delegate, seemed embarrassed and stressed that the infliction of corporal punishment was very rare and that her government had approved the law hoping that the possibility of such punishment would serve as a deterrent. For a brief analysis of the flogging campaign in Britain at the end of the nineteenth century and its connection with the "white slave panic" of the early twentieth century, see Angus McLaren, The Trials of Masculinity: Policing Sexual Boundaries, I870-I930 (Chicago, IL, I997), pp. I7-I9.

60. Committee, Minutes of the Seventh Session, Geneva, I2-17 March 1928, pp. 34, 36, LNA C.I84.M.59.1928.IV; League of Nations, Report of the Special Body of Experts: Part I, p. 39. 6r. Report of the Sub-Committee of the Traffic in Women and Children Committee, Geneva, 7 February I93I, pp. 2, I3-I4, LNA CTFE/CJ/2.

62. Foucault, Discipline and Punish, p. I8. 
prostitutes; living on the earnings of a prostitute; and recruiting "inmates" for foreign brothels. Other members were inclined to focus solely on the second accusation, namely making the prostitution of another person a source of livelihood. According to Estrid Hein (Danish delegate), all qualified as pimps. She classified the first category as "active" and the second one as "passive" souteneurs. To find a workable solution, the Committee proposed the establishment of a legal subcommittee. ${ }^{63}$

But the legal subcommittee too found it hard to define the factors constituting the offence of pimping. Like the League's Committee, the legal experts held differing opinions on the scope of the offence. However, they agreed on one issue: individuals who drew from the prostitution of others the whole or part of their livelihood ought to be "punished with particular severity". ${ }^{4}$ Technically, this elasticity meant that not only the prostitute's partner but also her maid, parents, children, doctor, or landlord who were living with her, or who received financial gain as a result of her activities could be punished on the basis of this definition. Profit, exploitation, and the close liaison between the prostitute and the souteneur were therefore emphasized in the additional protocol to the I92I Convention proposed by the legal subcommittee. ${ }^{65}$

An interesting gender dynamic arose from this debate. While most male members of the committees wished to prosecute any person guilty of pimping, female delegates insisted on applying the word "souteneur" exclusively to men. Male delegates protested and the phrase "person of either sex" was included in the protocol. However, during the debates pimps were invariably linked to the male sex. Elizabeth Zillken (German expert) and Estrid Hein explained this by claiming that "the very exact description given of a souteneur's character from the psychological point of view [that is, the intimate pimp-prostitute relationship] made it clear that a woman could not carry on the profession of souteneur" ${ }^{66}$ A woman could commit the same offence and be punished as a procuress but not as a souteneur. Hein's viewpoint was, however, more moderate. She thought that a distinction should be made between various categories of offender: "a brutal individual living on the immoral earnings of a

63. Committee, Minutes of the Eighth Session, Geneva, 19-27 April 1929, pp. 54, 58-59, LNA C.294.M.97.I929.IV; Committee, Minutes of the Twelfth Session, Fourth Meeting, I933, pp. 7-8; Report of the Sub-Committee of the Traffic in Women and Children Committee, 1931, p. 2. The sub-committee was composed of government representatives serving on the Legal Sub-Committee of the Child Welfare Committee, and academic and international police experts.

64. Report of the Sub-Committee of the Traffic in Women and Children Committee, I93 I, p. 3. 65. Legal Sub-Committee, Preliminary Draft International Convention on the Punishment of Persons who Live on the Immoral Earnings of Women, Geneva, 9 December 1930, p. 2, LNA $\mathrm{CTFE} / \mathrm{CJ} / \mathrm{r}$.

66. This and the following quotes are taken from Committee, Minutes of the Tenth Session, Geneva, 21-27 April 193I, pp. 21-22, 25-26, 28, 87, LNA C.40I.M.I63.193r.IV. 
woman should not be allowed bail, but other cases, for instance that of a wife who in desperation engaged in prostitution to provide for her unemployed husband and children, might call for a degree of clemency".

Furthermore, some Committee members pointed to another important difficulty with the draft protocol. The double aspect of the definition of a souteneur (intermediary of prostitution and profiteer) meant that it could include in its application the owners or managers of regulated brothels. As the protocol would indirectly lead to the suppression of licensed houses, it could be interpreted in abolitionist terms and meet with the opposition of regulationist countries. Self-proclaimed abolitionist members within the Committee such as Samuel Cohen (assessor representing the Jewish Association for the Protection of Girls and Women), Avril de Sainte-Croix, Estrid Hein, and Paulina Luisi had no objection to brothel keepers and pimps being treated similarly, "since they were also procurers and were always in agreement with the souteneurs".

After years of discussion and disagreement on the meaning of souteneur, Cohen provoked the Committee to shift its attention to an issue closely related to the recruitment of women for prostitution: the elimination of the age limit in the I9I0 and I92 I anti-traffic conventions. Like the question of penalizing third parties, the idea of punishing procuring regardless of age had first been raised in 1927, when Part I of the Report of the Special Body of Experts was under discussion. Seeing that forged passports and birth certificates were ubiquitous in the sex trade, that the age of consent was fixed as low as ten in some countries, and that it seemed extremely difficult to produce legal evidence that intermediaries had employed frauduent means or coercion, the experts suggested the removal of any mention of age from the existing conventions. The distinction drawn between adult women and minors was thus perceived as a legal tool with a perverse effect, as it facilitated the operations of intermediaries of prostitution. Hence it needed to be expunged from the international conventions. ${ }^{67}$

Most members of the Committee supported the elimination of the age limit. However, a few of them pointed to the objections some governments would pose to the proposal. Estrid Hein, for instance, explained that the Danish government would not support such an amendment "for it held the view that the liberty of action of adults should be respected". ${ }^{68}$ Isidore Maus too hoped that all governments would respond favourably to the elimination of the age limit, but pointed out that it was very probable that certain difficulties would arise in regulationist countries such as his own, Belgium. He explained that if the age limit was abolished,

67. Committee, Minutes of the Seventh Session, 1928, p. 37; Committee, Minutes of the Twelfth Session, Third Meeting, 1933, p. 4; League of Nations, Report of the Special Body of Experts: Part I, pp. 44-45.

68. Committee, Minutes of the Eighth Session, I929, p. 60. 
keepers of licensed houses or those who recruited women for regulated brothels would become subject to legal penalties. Yet Maus also thought that it was the Committee's duty to recommend the action it thought necessary, irrespective of the reservations of governments. ${ }^{69}$

The most moderate voice within this debate was (once again) that of Estrid Hein. She preferred a limited recommendation that would apply only to international traffic. Hein feared that an unconditional amendment to the conventions might lead to the prosecution of innocent third parties and indirectly to the infringement of the liberty of adult women who consent to prostitution. ${ }^{70}$ In her view, "it was not felt desirable to protect adults against the consequences of acts they voluntarily committed". ${ }^{71}$ However, Hein's allusion to the necessity of protecting the freedom of individuals was deprecated by the rest of the Committee. F.A.R. Sempkins (International Anti-Traffic Bureau) thought that "the principle at stake took priority over the interests of the individual". Paulina Luisi, an otherwise outspoken defender of women's rights, was also convinced that the "abolition of the age limit would certainly interfere with the freedom of adults [...], but it was the Committee's duty to combat the crime of procuring whatever the age of those concerned". Individual choice of prostitution abroad was inconceivable. As a French delegate argued, "it could not be maintained that these unfortunate women ever really gave their consent". ${ }^{72}$

Nonetheless, Hein's suggestion of restricting the elimination of the age limit to international traffic did not pass unnoticed, particularly by representatives of regulationist countries. The French delegation readily picked up the idea and stressed that international traffic could easily be identified and represented a far greater danger than national traffic. By launching a proposal that restricted the abolition of the age limit to cases of adult and minor women being recruited for prostitution abroad, the French could score twice, both on the domestic and the international level. On the one hand, the sovereignty of regulationist countries would remain intact as recruiters for or owners of licensed brothels would not be convicted on the basis of the new convention; on the other, limiting the issue to all women going abroad would deal a blow to the so-called international traffic, as the recruitment of foreign females of every age

69. Committee, Minutes of the Ninth Session, Geneva, 2-9 April 1930, p. 37, LNA C.246.M.I21.1930.IV.

70. Committee, Minutes of the Eleventh Session, Fifth Meeting, Geneva, 6 April 1932, p. 3, LNA CTFE/I Ith Session/PV.5; Committee, Minutes of the Twelfth Session, Third Meeting, I 933, p. 7.

7I. The following quotations are taken from Committee, Minutes of the Eleventh Session, 1932, pp. 3, 5-6, 8 .

72. Committee, Minutes of the Twelfth Session, Fourth Meeting, Geneva, 7 April 1933, p. 2, LNA CTFE/r 2th Session/PV.4(I). 
would henceforth be criminalized. ${ }^{73}$ Abolitionist members within the Committee unanimously supported the French amendment and declared themselves prepared "to compromise and to accept the immediate international remedy now proposed, as a step towards a complete abolition of the souteneur from national as well as from international traffic". ${ }^{74}$

In 1933, the League's Assembly approved the International Convention for the Suppression of the Traffic in Women of Full Age. It covered "the offence of procuring, enticing or leading away, even with her consent, a woman or girl of full age for immoral purposes in another country" ${ }^{75}$ This approval was perceived as a triumph of the Committee's joint action between state and non-state actors - to combat the traffic in women and children. As the Spanish delegate to the Committee observed, "the restriction of the export traffic from France would have the beneficial effect in Spain of preventing the entry of French women, for whom there was a special demand", and "action by the Spanish authorities would prevent the export of Spanish women to South America". ${ }^{6}$ Whether the 1933 Convention helped to prosecute genuine offenders of human trafficking and whether it was beneficial to the women it sought to protect is doubtful. As Marjan Wijers argues, restrictive measures easily give rise to increased clandestine action, punishment of innocent people, restriction of personal freedom, stigmatization, and the social exclusion of the men and women engaged in the sex trade. ${ }^{77}$

The campaign for the protection of foreign women of all ages did not distract the Committee from its earlier effort to punish intermediaries of prostitution. During the early i 930 s, the Committee debated the best way to transcend the main difficulty - whether or not to penalize the manager of licensed brothels - and to draft a convention that would be acceptable to as many countries as possible - abolitionist and regulationist. Seeing that the Committee could not find a suitable solution to this issue, the League's Assembly called on the International Bureau for the Unification of Criminal Law for assistance. The Committee would provide the "moral substance" and the Bureau the legal form. ${ }^{78}$

73. Committee, Minutes of the Eleventh Session, I932, pp. 7, 9-10; Committee, Minutes of the Twelfth Session, Third Meeting, 1933, pp. 2-4, 7, 9 .

74. Committee, Minutes of the Twelfth Session, Third Meeting, 1933, pp. 5-7.

75. Ibid., p. 7; Report of the Sub-Committee [...] Second Draft of a Convention for Suppressing the Exploitation of the Prostitution of Others, 1937, p. 3.

76. Committee, Minutes of the Twelfth Session, Third Meeting, I933, p. 6.

77. Marjan Wijers, "European Union Policies on Trafficking in Women", in Mariagrazia Rossilli (ed.), Gender Policies in the European Union (New York, 2000), pp. 209-229, 219, 227. Wijers analyses recent European policies on traffic but draws many parallels with the campaigns and policies of the early twentieth century.

78. Committee, Minutes of the Thirteenth Session, Geneva, 4-I2 April 1934, pp. 4-5, 83, 94-95, LNA CTFE/I 3 th Session/PV (revised). 
By the mid-I930s, the Committee's enquiry into the system of regulation provided sufficient ammunition for the criminalization of all forms of recruitment for prostitution. Since the system of licensed or tolerated brothels had not attained its main objective (the prevention of venereal diseases), the Committee reached three important conclusions: regulation of prostitution could not be justified; brothels of all kinds ought to be prohibited; and brothel keepers, procurers, and souteneurs should be punished. ${ }^{79} \mathrm{~A}$ new draft convention was prepared to make all procurement illegal, but some Committee members did not support it, for two reasons. Sidney West Harris (British representative) thought that there could be "no effective convention for the punishment of souteneurs if the problem of licensed houses was not first solved". For his part, the International Anti-Traffic Bureau's delegate, Sempkins, regretted that the Convention "made little provision for dealing with the souteneurs and was mainly concerned with procuring". 80

In 1935, a legal subcommittee was appointed to find a solution to the impasse. To obtain the approval of regulationist countries, the new draft convention omitted the term "souteneur". At the same time, it wished to give immediate satisfaction to the aspirations of abolitionist countries and supporters by implicitly targeting "all those who recruited women for the purpose of immorality" ${ }^{\mathrm{I}}$ The draft Convention for Suppressing the Exploitation of the Prostitution of Others (1937) was intended to fill the gap in the existing conventions by protecting adults of either sex against procuration, even when they consented and were not taken abroad. ${ }^{82}$ The outbreak of World War II prevented its approval by the Assembly, but many of the ideas included in the draft convention were taken up by the United Nations in $1949 .{ }^{83}$

One of the two pillars that sustained the League's moral recruitment of women - repression of offenders - remained thus intact throughout the I920s and I930s. By 1939, however, as the Committee started to treat

79. Abolition of Licensed Houses, Geneva, is June 1934, pp. 94-95, LNA C.22 I.M.88.1934.IV; Committee, Minutes of the Fourteenth Session, Fourth Meeting, Geneva, 4 May 1935, pp. 2-3, LNA CTFE/I 4 th Session/PV.4.

80. Committee, Minutes of the Fourteenth Session, Fifth Meeting, Geneva, 1935, pp. 2-3, 6, LNA CTFE/r 4 th Session/PV.5.

8I. Sub-Committee on the suppression of the activities of souteneurs, Geneva, 25 January 1936, p. 9, LNA CTFE/CS.4.

82. Report of the Sub-Committee [...] Second Draft of a Convention for Suppressing the Exploitation of the Prostitution of Others, 1937, pp. 2-3.

83. The UN Convention for the Suppression of the Traffic in Persons and of the Exploitation of the Prostitution of Others called on states to suppress trafficking and prostitution, regardless of the consent of the people involved. But as Harris had predicted, not many states ratified the I949 Convention, partly because of its abolitionist goal; Joyce Outshoorn, "Introduction: Prostitution, Women's Movements and Democratic Politics", in idem (ed.), The Politics of Prostitution: Women's Movements, Democratic States and the Globalisation of Sex Commerce (Cambridge, 2004), pp. I-20, 8; the Convention's text is available at http://www2.ohchr.org/ english/law/trafficpersons.htm, last accessed 6 December $20 \mathrm{II}$. 
prostitution from a psychiatric viewpoint, its perception of intermediaries for prostitution altered slightly. Backed by the expertise of the Director of the University Institute for Human Genetics (Copenhagen), Dr Tage Kemp, the Committee observed a strong parallelism between the "mental state of prostitutes" and that of souteneurs. The Committee discovered that, like many prostitutes, a large percentage of souteneurs could be classified as "dull, feeble-minded, or clearly even psychopathic". ${ }^{4}$ Hence the Committee wished not only to criminalize but also to investigate the social conditions under which the phenomenon of pimping appeared. Regardless of the motives and mental attributes of recruiters, the Committee invariably thought that females needed to be protected.

Concrete action for the protection of women had been the competence of voluntary organizations since the second half of the nineteenth century. From its origins, the Committee paid due attention to the issue. However, it was especially after the publication of the investigations on trafficking and regulated brothels that all of its members (governmental and non-governmental) showed great interest in the protection of women. Particularly during the I930s, the Committee formulated strong views on rehabilitation and the prevention of prostitution. The following pages illustrate the Committee's ideas in more detail.

\section{PROTECTION OF WOMEN}

International organized women were divided on issues such as the urgency of moral reform and the need to protect women. Feminists such as Paulina Luisi feared that protective measures would result in discriminatory control of women. ${ }^{85}$ Although Luisi regularly aired these concerns within the League of Nations, most members of the Committee agreed on the need to establish protection strategies that would prevent women and young girls from entering into prostitution and from becoming victims of traffic. Contrary to what some authors suggest, ${ }^{86}$ the majority of women's groups represented at the Committee did support initiatives for the protection of women. Furthermore, "rescue missions" were not only endorsed by religious or secular organizations associated with the (rather conservative) International Anti-Traffic Bureau but also by women's organizations closely linked to the International Abolitionist Federation (commonly viewed as more progressive).

84. Committee on Social Questions, Report on the work of the Committee in 1939 (Third Session), Geneva, July 1939, p. I6, LNA C.2 I4.M.I42.1939.IV.

85. Rupp, Worlds of Women, pp. I I-I 52; Summers, "Which Women?”, p. 223.

86. Carol Miller, "The Social Section and Advisory Committee on Social Questions of the League of Nations", in Paul Weindling (ed.), International Health Organisations and Movements, 1918-1939 (Cambridge, 1995), pp. I 54-174, I58-159; Limoncelli, The Politics of Trafficking, pp. $75-76$. 


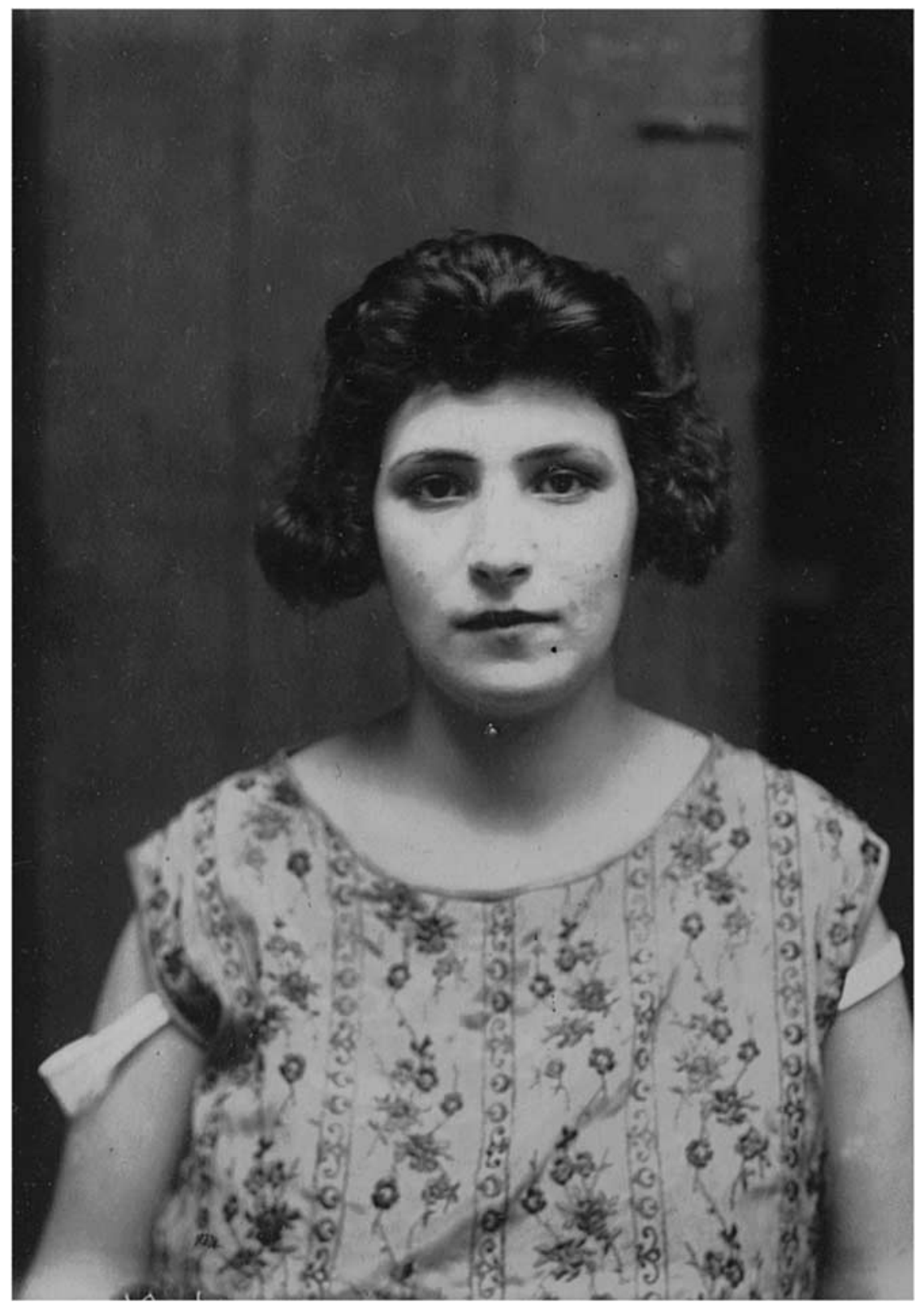

Figure 3. Photograph album of traffickers, souteneurs, and prostitutes, obtained from the chief of the judicial police, Havana (c.1927), "PROSTITUTE. Lonya Vavionsha. Born in Poland, 25 years of age. Father - Adolph, mother - Anna. Prostitute at 9 Bernat Street, Havana, Cuba. Was imported for purposes of prostitution by trafficker ANNA GRIEF SEIMAN.” UNOG Library, League of Nations Archives, Geneva. Used with permission. 
The yearly reports of the non-governmental associations represented in the Committee are testimony to the continuation and strengthening of protective measures. For instance, Avril de Sainte-Croix proudly informed her peers that the International Council of Women (ICW) had agreed to organize "an international system of female supervision" on board ships. ${ }^{87}$ The ICW hoped to reach an agreement with shipping companies, as it felt that women were relatively well protected in stations and ports but not en route. ${ }^{88}$ Similarly, Samuel Cohen informed the Committee on the successful activities of the Jewish Association for the Protection of Girls and Women in ports, railway stations, and long-distance coach termini which had led to the prosecution and conviction of men, and to the restoration of girls "to a respectable life". ${ }^{89}$ Like de Sainte-Croix, Cohen wished to obtain better arrangements with transport companies to refuse passage to those suspected of trafficking, to patrol stations, ports, and ships, and to be allowed to post warning notices on vessels pointing to "the dangers that might be encountered on the particular route".$^{\circ}$ For his part, the French delegate Bourgois regretted that many of the questions dealt with by voluntary organizations were "more concerned with social hygiene than with traffic".

Indeed, a moral rather than a liberal-feminist or humanitarian perspective dominated the debate on rescue work. Avril de Sainte-Croix, for example, shared Paulina Luisi's concern about restrictive regulations governing the travel of adult women, but insisted at the same time on the need to "afford protection to unprotected women and to girls and children in moral danger". From the evidence found in the Committee's documents, one gets the impression that many female members within the Committee had a generally negative perception of men - or at least of male migrants - that was often based on speculation. For example, Mrs Curchod-Secretan (Fédération des Unions Nationales des Amies de la Jeune Fille) reported to the Committee that:

[...] one of our station representatives sees a charming young girl get out of the train one morning, followed by a suspicious-looking man who appears to be taking great care of her. "Where are you going?", asks our representative. "I am going to B.", replies the girl, "but not at once; this gentleman has offered to show me round the town, and we are going to dine together". Our representative puts the girl back into the train and points out to her the danger of changing one's plans. Meanwhile, the disreputable gentleman disappears. ${ }^{9 \mathrm{I}}$

87. Committee, Minutes of the First Session, 1922, pp. 46-47.

88. Monitoring of places of departure was already included in the 1904 International Agreement for the Suppression of White Slave Traffic (see above).

89. Committee, Minutes of the First Session, 1922, p. 46.

90. The following quotation are taken from Committee, Minutes of the Third Session, 1924, pp. $26-27,80$.

91. Committee, Minutes of the Fifth Session, 1926, p. 92. 
Hence Avril de Sainte-Croix applauded the initiative of women's organizations to establish separate clubs, canteens, and "foyer féminins" to provide young working women with cheap food and lodging, and stressed that "by offering them a refuge from men's attentions in the restaurants, [these organizations] have saved many [women] from the great dangers to which bad company exposes young girls". ${ }^{92}$ Adéle Thurler (International Catholic Association for the Protection of Girls) too described her organization's rescue work as "an outpost, preventing the treacherous enemy from penetrating to the citadel". ${ }^{93}$ A strong gendered logic of men being a danger for women and of women being in danger of men guided the thought and actions of many female delegates and assessors. For their part, male representatives were more inclined to stress female vulnerability rather than male menace.

Influenced by these fears, the more permissive climate of the I920s and I930s was not interpreted in terms of opportunity for women's empowerment. On the contrary, the sexual revolution of the early twentieth century only aggravated the Committee's preoccupation with moral degradation and female libertarianism. Many female representatives showed great concern about the relaxation of parental authority and excess of liberty granted to young people, which "was creating a problem not of commercialized traffic but of promiscuity". ${ }^{94}$ A Canadian assessor regretted that the single moral standard was approached by a route that had not been anticipated and that "increased knowledge of contraceptives and greater freedom tended [...] to diminish the seriousness of immorality and irregular sexual relations in the eyes of women". What was needed, she said, was "intensive education, character training and attention to the attitude, especially that adopted by women, towards morality, chastity and virtue".

Moreover, following in the footsteps of international women's organizations, many within the Committee seemed convinced that moral and sexual education was not only of paramount importance but also a right and responsibility of women. ${ }^{95}$ For instance, through the League of Nations, Avril de Sainte-Croix successfully propagated the ICW campaign for the worldwide establishment of a women's police force, which they considered essential for any serious reform of public morals.

92. Committee, Minutes of the Third Session, 1924, p. 8 I.

93. Committee, Minutes of the First Session, 1922, p. 4I.

94. The following quotation are taken from Committee, Minutes of the Fifteenth Session, Fifth Meeting, 22 April 1936, pp. I0-I 2, LNA CTFE/ı sth Session/PV.s.

95. Catherine Jacques and Sylvie Lefebvre, "From Philanthropy to Social Commitment", in Éliane Gubin and Leen Van Molle (eds), Women Changing the World: A History of the International Council of Women, I888-1988 (Brussels, 2005), pp. I49-169, I49, 161; Rupp, Worlds of Women, p. Is 4 . 
In their opinion, in questions concerning the defence of women and children "women should be called upon to lend their abilities and devotion" ${ }^{96}$ Avril de Sainte-Croix also praised the efforts of the Société française de prophylaxie sanitaire et morale, in particular its campaign against venereal diseases and the importance attached to the mother in sexual education. ${ }^{97}$ It was necessary, in her view, "to impress the young with the dangers of the traffic and of immorality" because "the main cause of prostitution was environment and the evil could be combated only by giving young people of either sex moral education and a sense of responsibility and self-respect". ${ }^{8}$

On the causes of prostitution, the divisions within the Committee were profound. This debate arose for the first time in 1927, after the Body of Experts had presented evidence of the influence of low wages on the development of prostitution and trafficking. The economic depression of the early I930s intensified the debate, but it did not resolve those divisions. Various governmental and non-governmental members - Paulina Luisi and Isidore Maus, and Avril de Sainte-Croix and Baroness de Montenach respectively - thought that there was a strong relationship between low wages and prostitution and, therefore, wanted a prompt investigation of the subject. To prove her argument, De Sainte-Croix used the example of "a young, refined girl" whom she had asked "whether the life she led did not disgust her", and to which the girl had replied: "my body is my own, and while I am about it I would rather sell it for an hour for 10 francs than for ten hours work a day for a miserable wage". ${ }^{99}$ For his part, Sidney Harris (Britain) did not believe the connection between wages and prostitution was clear-cut and, above all, he thought the issue involved a major economic question that lay outside the scope of the Committee's competence. Nonetheless, the Committee recognized that the low wages paid to women in certain branches of employment was a factor that could not be disregarded and suggested that the League's Secretariat should examine the question in cooperation with the International Labour Organization (ILO). ${ }^{\mathrm{I} 0}$ To my knowledge, no joint study emerged from this suggestion.

96. Committee, Minutes of the Eighth Session, 1929, p. I I6; Committee, Minutes of the Fifth Session, 1926, p. 25 .

97. Committee, Minutes of the Sixth Session, Geneva, 25-30 April 1927, p. 4I, LNA C.338.M.II3.1927.IV.

98. Committee, Minutes of the Fifth Session, 1926, p. 89; Committee, Minutes of the Thirteenth Session, 1934, p. 23.

99. Committee on Social Questions, Reports of voluntary organizations, 27 April 1937, p. 3, LNA CQS/A.Io.

100. Reports on the Work of the Advisory Committee during its Sixth Session held at Geneva from 25-30 April 1927, Geneva, July 1927, p. 5, LNA A.25.1927.IV. 
No agreement could be reached regarding the influence of unemployment on prostitution. Avril de Sainte-Croix claimed that her enquiries and those from colleagues all over the world had led her to conclude that undue importance was attached to unemployment. Lack of work could not be seen as a direct cause of prostitution since domestic servants, shop girls, stenographers, and so on accounted for a large proportion of prostitutes. In her view, idleness, coquetry, greed, bad company, and sybaritism had more "corrupting" effects. The Danish, German, Polish, and Uruguayan delegates (all female) - Hein, Zillken, Grabinska, and Luisi - strongly disagreed. In their view, want, unemployment, and social inequality were indisputably linked to prostitution. ${ }^{\mathrm{OI}}$

Whatever the causes of prostitution, the Committee unanimously agreed that providing "a suitable and decent livelihood for the women of the less favoured classes" could safeguard them from being recruited for prostitution and trafficking. ${ }^{102}$ A peculiar mix of feminism and conservatism was often discernible in the discussions on the prevention of prostitution through work and the place of women in society in general. At the Committee's fifth session, Avril de Sainte-Croix defended with verve her ideas on gender equality: a woman, she said, deserved the same opportunities as a man to expose her ideas, "without prejudice to her essential mission as guardian of the home". ${ }^{103}$ Similarly, a delegate of the International Union of Catholic Women's Leagues urged an enquiry into the effects of female unemployment on prostitution, but wanted at the same time to create social institutions "to facilitate the return of the mother to the home" ${ }^{104}$ Yet realizing that economic factors compelled many women to work, all Committee members found it necessary to improve the socio-economic position of women to prevent them from entering into prostitution.

From the nineteenth century on, voluntary associations had established non-profit employment bureaus and rescue homes where training and workrooms for women were organized. Voluntary female workers acted as a link between the "inmates" and the world outside. The yearly reports of the non-governmental assessors informed the Committee of their continuous efforts to secure jobs and to "inculcate in young girls a love of work". ${ }^{\text {Oos }}$ As stated in the Committee's study on the prevention of

I0I. Ibid., pp. I6-1 8, 23, 26-27; Committee, Minutes of the Sixth Session, 1927, pp. I6-17, 37; Committee, Minutes of the Eighth Session, I929, p. I 16; Committee, Minutes of the Eleventh Session, Fourth Meeting, Geneva, 5 April 1932, pp. 3, 7, 9, I6, LNA CTFE/ı Ith Session/PV.4; Committee, Minutes of the Fifteenth Session, Fifth Meeting, 1936, p. 9.

102. Committee, Minutes of the Thirteenth Session, 1934, p. I 5 .

103. Committee, Minutes of the Fifth Session, 1926, p. 87.

104. Committee, Minutes of the Thirteenth Session, 1934, p. I7.

I05. Committee, Minutes of the Fourteenth Session, Third Meeting, 1935, p. 7. 
prostitution, the idea was to provide "protection by means of work". ${ }^{106}$ The Committee had come to the conclusion that although certain forms of employment (such as domestic service or jobs in bars, dance halls, and other public places) "may cause moral danger", a lack of occupation was no less risky. Furthermore, in addition to unemployment, working conditions also demanded attention. Wages and the status of some occupations needed improvement to protect women against the "temptation to find a way out by taking up a shameful but profitable trade".

Work was thus to be made attractive to women, but it needed to be monitored. The Committee applauded the efforts of voluntary organizations, which sought cooperation with ministries of labour and private employment agencies to obtain not only working permits for foreign girls but also "moral guarantees" for jobs abroad. ${ }^{107}$ Another crucial partner for the task of promoting and supervising female labour was the ILO. In the Committee's study on prevention of prostitution, the ILO authored the chapter "Moral Protection of Young Women Workers". ${ }^{108}$ Its analysis focused on three measures: regulation of placing operations; protection at the workplace; and protection of female workers during their spare time.

A radical measure for the regulation of job placement was adopted in 1933, when the International Labour Conference adopted a convention to abolish all fee-charging employment agencies and to supervise non-profit bureaus working under the mask of philanthropy. Among the important provisions for the protection of women at the workplace were the conventions on the minimum age for industrial and non-industrial employment. Supervision of employment in the entertainment industry, restaurants, public houses, and domestic service in particular called for greater attention. Because a statistically significant number of prostitutes had previously worked as domestic servants in private households, the ILO wished to strengthen its efforts to improve domestic work, but it admitted that progress was slow. ${ }^{109}$ According to the ILO, an increased appreciation of domestic work as a profession was as important as improved working conditions. Women who took up domestic service ought to "feel that they had a real vocation and should not be ashamed of their work". ${ }^{\text {I }}$

On the protection of young women outside working hours and during holidays, the ILO had to admit that legislation on the subject was

106. The following quotations are taken from Committee on Social Questions, Prevention of Prostitution: A Study of Preventive Measures, Especially Those which Affect Minors, Geneva, is May i939, pp. 60-6i, LNA CQS/A/r9(a) [hereafter, "Study of Preventive Measures"].

107. Committee, Minutes of the Third Session, 1924, p. 83.

108. The following quotations are taken from "Study of Preventive Measures", pp. 45, 57-63. ro9. The ILO Convention Concerning Decent Work for Domestic Workers was adopted in June $20 \mathrm{II}$.

I 10. Committee, Minutes of the Fifteenth Session, Fifth Meeting, I936, p. 4. 
restricted. Since spare time did not belong to the employer-employee relationship, the recreation activities organized by charitable associations were of crucial importance. The ILO found four types of private initiative that at the time of writing (1939) were apparently worth mentioning: youth hostels; Christian workers' organizations; social service or adult education associations; and institutions organized by political parties, such as the socialist women's groups in Belgium and the Hitler Youth in Germany. Among the activities organized by public authorities, the ILO took the German, Italian, and Soviet tourist services as examples. Obviously, the ILO explained, the objective of all these initiatives was not merely recreational. The educational aim was to teach "young persons of both sexes to live in normal, healthy friendship". ${ }^{\text {I }}$

Indeed, one major goal underlay the initiative of the League of Nations with regard to women's safety: the protection of morality. Using the social measures taken by the Cuban government as an exemplary case, the Committee stressed the relation between public morals and the improvement of the economic position of women. Intolerable economic conditions were seen as a menace to the normal functioning of the community. Therefore, the Committee emphasized "the importance of preserving a stable family life as a major factor in prevention", and vehemently insisted on the elimination of the double standard of morals. ${ }^{\text {II }}$ "Respectable" jobs, education, recreation, and control of the sexual behaviour of the young, both men and women, would contribute to the successful protection of women against the intermediaries of prostitution.

\section{CONCLUSION}

Judging the achievements of the League of Nations is inherently difficult. In theory and on the supranational level, the Committee's efforts in what I have called the "moral recruitment of women" were successful. On the one hand, the interplay between governmental and non-governmental representatives within the Committee contributed to the strengthening of a global prohibition regime against the recruitment of women for prostitution with the approval of the Convention for the Suppression of International Traffic of Consenting Adult Women in 1933, and the draft

I I I. "Study of Preventive Measures", pp. 61, 70-73. In Europe, leisure time became increasingly formalized, regularized, and institutionalized from the eighteenth century onward. During the interwar period, the organization of leisure was a powerful control mechanism of authoritarian regimes. For analyses of the organization of leisure time in Italy and Germany see Victoria de Grazia, The Culture of Consent: Mass Organisation of Leisure in Fascist Italy (Cambridge, 2002), and Shelley Baranowski, Strength Through Joy: Consumerism and Mass Tourism in the Third Reich (Cambridge, 2007).

I I 2. Committee on Social Questions, Report on the Work of the Committee in 1938 (Second Session), Geneva, 6 May 1938, p. I8, LNA C.147.M.88.1938.IV. 
convention against the national and international procurement of consenting adults in 1937, which formed the basis of the 1949 UN Convention. On the other, it bolstered public and private initiatives for the protection of women and developed strong views on the prevention of prostitution and rehabilitation of prostitutes. This moral recruitment of women was meant to provide for both the punishment of undesirable activities and the protection of women and societal order.

However, the actual impact of these policies is hard to measure. As with all international conventions, the differentiation between ratification by member states and de facto implementation at the national level must be emphasized. ${ }^{\mathrm{II} 3}$ Whether the Committee's ideas were transformed into concrete reform of domestic legislation and judiciary systems to suppress effectively intermediaries of prostitution remains thus far unclear. As Ethan Nadelmann suggests, activities that require limited resources and no particular expertise, that are easily concealed or unlikely to be reported to the authorities, and for which the demand remains substantial are difficult to repress, ${ }^{\mathrm{II} 4}$ and to research. I suspect that the ideas of the League of Nations, reflected in the United Nations after 1945, had at least some impact on countries such as Belgium, France, Greece, Italy, or Japan, which were moving towards abolitionism after the war. Yet the degree to which signatories conformed to the anti-trafficking international agreements and the repercussions of criminal laws on offenders (presumed and otherwise) require further study, particularly in national and local archives.

The Committee's influence on initiatives aimed at the protection of women is equally hard to gauge. Since the Committee did not engage in preventive or rehabilitation programmes, its impact could not have been other than indirect. The League's archives give evidence of the strong appreciation among public authorities and voluntary organizations of the Committee's support, which mainly consisted of information gathering. Akin to other international organizations, the League of Nations played an important role as a clearing-house for the compilation and dissemination of information on international traffic and protective and preventive measures. Furthermore, the Committee's collaboration with the International Labour Organization, psychiatric and legal specialists, as well as international police experts, strengthened the League's credibility. As is the case with contemporary international institutions, the Committee's findings gave "force and symbolic representation to the moral values, beliefs, and prejudices" IIs of all those private associations and state actors

I I 3. Magaly Rodríguez García, “Conclusion: The ILO’s Impact on the World”, in Jasmien Van Daele et al. (eds), ILO Histories: Essays on the International Labour Organization and Its Impact on the World During the Twentieth Century (Berne, 2010), pp. 46I-478, 462.

I I4. Nadelmann, "Global Prohibition Regimes", p. 525.

I I s. Ibid., p. 48 I. 
that strove to protect women and eradicate all forms of recruitment of women for prostitution.

How these protective measures affected women is open to question. On the basis of the material found in Geneva, one can only conclude that the discourse of the League of Nations on human traffic turned into a social purity crusade to abolish state regulation and, ideally, prostitution in general. Liberal-feminist, humanitarian, and regulationist points of view within the Committee became increasingly overshadowed by abolitionist arguments that sought to protect women's purity, to persuade men to live virtuously, and to punish all those (men in particular) who threatened these moral goals. Whereas abolitionist and feminist members of the Committee opposed state control of women, they strengthened the idea of private policing or female patrolling through rescue organizations and women's police forces to bring both men and women back on the right track.

Although there were some differences of opinion between female and male members of the Committee, particularly with regard to the identification of danger with the male sex, they unanimously agreed on three issues: prostitution was defined as a social evil that needed to be either controlled according to regulationists or eliminated according to abolitionists; intermediaries of prostitution were considered dangerous to women and society in general; and prostitutes were seen as persons who threatened the ideal image of woman/motherhood and who needed all possible help to escape "immorality". Through its Advisory Committee on Traffic in Women and Children, the League of Nations strengthened the gendered roles and assumptions that surrounded the sex industry and contributed to the stigmatization, marginalization, and social exclusion of the men and women involved in the sector. Several decades would pass before sex workers started to express their own views on the nature and organization of their profession. The voices of intermediaries of prostitution remain thus far silent. 